\title{
Electroscope for purposes of demonstration
}

\section{B. Kolbe}

To cite this article: B. Kolbe (1888) Electroscope for purposes of demonstration, Philosophical Magazine Series 5, 26:162, 467-468, DOI: 10.1080/14786448808628298

To link to this article: http://dx.doi.org/10.1080/14786448808628298

曲 Published online: 29 Apr 2009.

Submit your article to this journal 준

Џ Article views: 2

Q View related articles $\asymp$ 
ON THE CHANGES IN THE SPECIFIO HEAT OF LIQUIDS NFAR THE CRITICAL TEMPERATURE. BY P. DE HEEN.

The author used the method of cooling. The steel coolingvessel is half filled with the liquid in question, and in order to produce a uniform temperature in the whole mass it rotates about a horizontal axis. After being heated it is enclosed in a copper envelope. For ether, amylene, and bromide of ethyle, there was at the critical temperature a sudden diminution in the specific heat.

\begin{tabular}{|c|c|c|}
\hline Ether & $\begin{array}{l}\text { perature. } \\
\left\{\begin{array}{l}185 \\
180\end{array}\right.\end{array}$ & $\begin{array}{c}\text { Specific heat. } \\
0.547 \\
1.041\end{array}$ \\
\hline Amylene .. & $\left\{\begin{array}{l}175 \\
170\end{array}\right.$ & $\begin{array}{l}0.773 \\
1.500\end{array}$ \\
\hline Bromide of ethyle. & $\left\{\begin{array}{l}220 \\
215\end{array}\right.$ & $\begin{array}{l}0.233 \\
0.852\end{array}$ \\
\hline
\end{tabular}

With aldehyde, which, however, decomposed, there were no analogous phenomena.

The author infers from the behaviour of the former substances that as the eritical temperature is reached the gas-forming molecules relinquish their closed curves and describe the rectilinear paths of Clausius.-Bulll. Ac. Roy, de Belg. [3] xv. pp. 522-528. Beiblätter der Physik, No. 9, 1888.

\section{ELFCTROSCOPE FOR PURPOSES OF DEMONSTRATION. BY B. KOLBE.}

This electroscope, which has been specially constructed for purposes of demonstration, is visible on a clear ground at a distance of 30 to 50 feet; and gives large deflections, for, when charged, the leaves are almost horizontal. They consist of red silk paper, and are hung in stirrups of fine silvered copper wire at the side of the brass rod, the upper knob of which has a diameter of 2 centim. The length of the leares is 3.5 to 4 centim., and the breadth about 0.4 centim. The end is provided with a semicircular enlargement which is twisted at right angles, so that it always presents a surface to the observer.

The conducting rod is insulated by a stout ebonite stopper.

It is important to choose a glass which conducts well, in order to get rid of the disturbing influence of the glass sides. Moreover the glass vessel must be so spacious that the leaves, even when charged, are at a distance of 0.5 to 1 centim. from the glass. If the glass is not a good conductor, the vessel should be so wide that the leaves (when horizontal) are at a distance of 2 to 2.5 centim. from the glass.

It appears hitherto to have been usual to take a good insulating 
glass for electroscopes, by which these apparatus, especially those with gold and aluminium leaves, often fail in dry air ; for such glass acts like a condenser, and only discharges slowly. It is true that good conducting glass is difficult to meet with. Among 184 kinds which I tried I only found 19 which I could use, and only three of these were good: the trouble is, however, rewarded by the never failing working of the electroscope.

If the paper strips are cut off 1 to 2 millim. below the loop, and fine aluminium strips ( 4 millim. in breadth and 3 to 4 centim. in length, with rounded ends) are fixed on, an electroscope of extraordinary delicacy is obtained. My electroscope of this construction, with condensing-plates of $6 \cdot 5$ centim. diameter, gave a deflection of $55^{\circ}$ when the plates were touched with the poles of a bichromate element, while an ordinary aluminium electroscope showed only $15^{\circ}$.

With this aluminium electroscope we can show very distinctly the difference between the arrangement of elements in series and abreast. In the former case, with two Bunsen's elements, the leaves stand almost horizontal.-Zeitschrift für Phys. und Chem. Unterricht, vol. iv. p. 182. Beiblätter der Physik, No. 7, 1898.

ON THE VELOCITY OF SOUND IN LIQUIDS. BY T. MARTINI.

The principal results of the investigation are as follows :-

1. Wertheim's hypothesis that a cylindrical column of liquid vibrates like a solid cylinder is untenable; the smallness of Wertheim's numbers arises rather from the influence of the sides of the tubes.

2. The velocity of sound in water increases with the temperature within the ordinary limits of temperature.

3. The velocity of sound in other liquids increases with the temperature.

4. When gases, liquids, or solids are dissolved in water the velocity of sound increases; this is also the case with other liquids, such as alcohol, which absorbs water, or turpentine in which resins are dissolved.

5. The velocity of sound in saline solutions increases with the quantity of salt dissolved.

6. Solutions of different salts reduced to the same degree of concentration have different velocities.

7. If the same weight of different salts are dissolved in the same weight of water, very different numbers are obtained; these are much greater with salts containing water than with anhydrous salts.

8. If the same weights of anhydrous and of a hydrated salt are dissolved, the velocity of sound in the former is greater than in the latter.-Beiblätter der Physik, No. 8, 1888 ; from Atti del. R. Ist. Venet. (6) 6. 